\title{
THE CATHOLICON OF THE MONASTERY OF AGIOS PANTELEIMON ON THE ISLAND OF IOANNINA, GREECE
}

The monastery is located at the southeast end of the settlement of the Island of Ioannina (Fig. 1) and became widely known in modern history after Ali Pasha, the ruler of the Pashalik of Yanina, was assassinated in its cells in 1822 by the troops of sultan Mahmud II ${ }^{1}$. However, the monastery's existence is historically documented as going back much earlier, as it is mentioned in the autobiography of the monks Nektarios and Theophanis, who were brothers and descendants of the noble Byzantine family of Apsarades from Ioannina in 1506/15072. It is also known that the Apsarades founded the neighboring monastery of Agios Ioannis Prodromos $^{3}$. The two brothers mention in their autobiography that next to the monastery of Prodromos there was a small hermitage of Agios Panteleimon, where a monk named Antonios was staying ${ }^{4}$. The monastery of Agios Panteleimon is mentioned in many wills and memoirs from 1643 onwards ${ }^{5}$. Therefore, its existence has been historically presumed at least since the $15^{\text {th }}$ century.

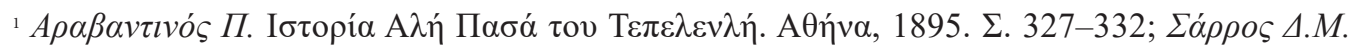

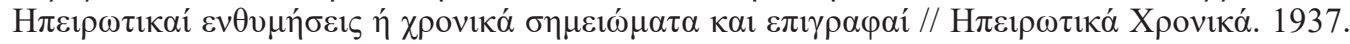
T. 12. $\Sigma .121-122$.

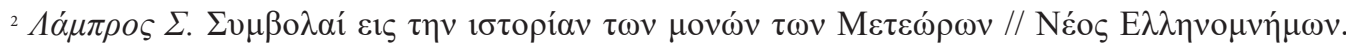

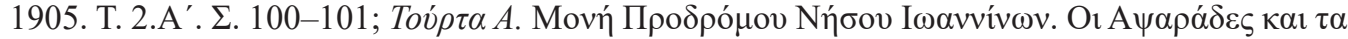

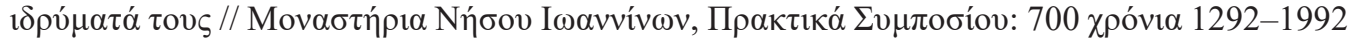

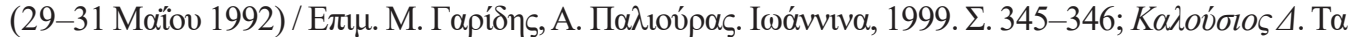

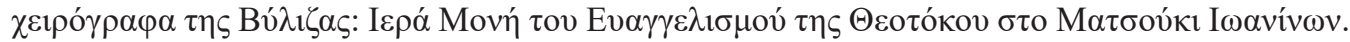

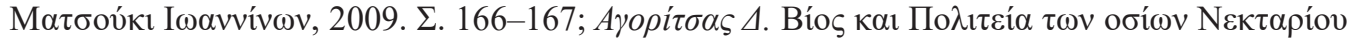

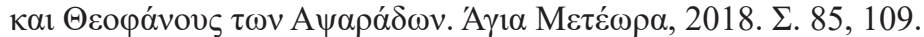

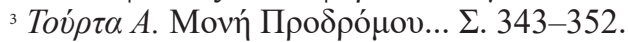

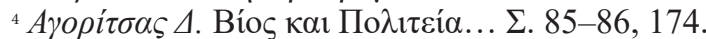

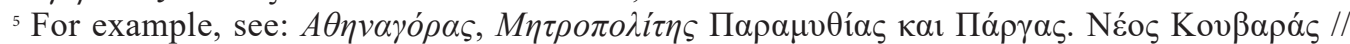

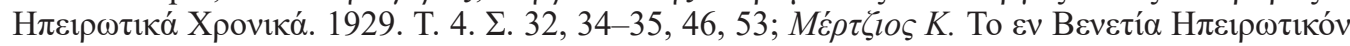

(C) Ioannis P. Chouliarás, 2020 
The catholicon today is a three-aisled basilica with a quadruple roof and in its present size was probably built in late $17^{\text {th }}$ or early $18^{\text {th }}$ century (Fig. 2). The aisles are

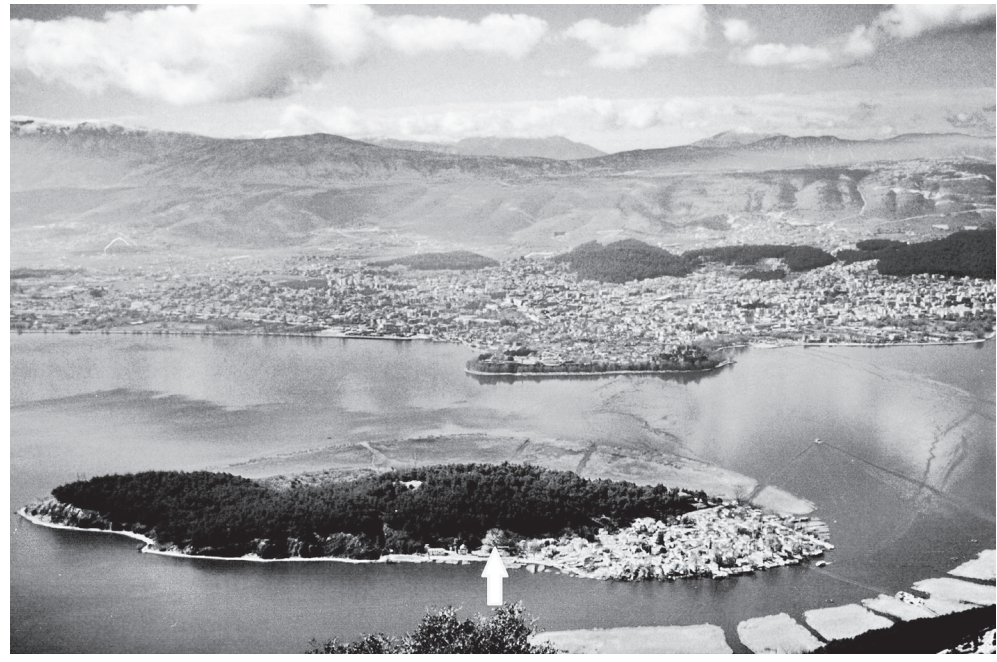

Fig. 1. Ioannina and the Island. The position of the monastery of St. Panteleimon is marked with the arrow.

Foto I. P. Chouliarás, 1995 separated by wooden colonnades. The west and north walls, probably most of the east, were rebuilt after their destruction by falling rocks in the early $19^{\text {th }}$ century ${ }^{6}$. In the east there is a semicircular arch. The original church was supposed to be small and oneaisled with a semicircular arch, traces of which were discovered on the southeast side of the modern church ${ }^{7}$.

From the early building phase the modern church has incorporated part of the south wall, which dates to the early $15^{\text {th }}$ century ${ }^{8}$ (Fig. 3 ). Along the south wall a late $19^{\text {th }}$ century loggia was added, which has a sloping roof lower than that of the church, and possibly replacing an older one. The only column of the loggia comes from an earlier building phase of the church ${ }^{9}$. On the west side there is a rectangular narthex, possibly of the same date as the loggia, which is roofed with a quadruple roof. The present entrance door to the main church is located at the western end of the south wall, while the original door was in the middle of the same wall and has been walled today. There is a small conch above the walled door. An entrance door also opens to the south wall of the narthex. The catholicon, the loggia, and the narthex are covered with slates. The floor of the catholicon is covered with large rectangular stones. A small lighting hole opens in the arch, a window in the north wall of the sanctuary and three more in the north wall of the nave.

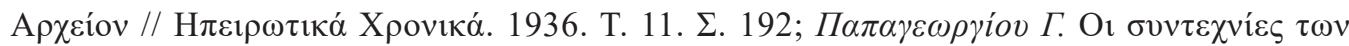

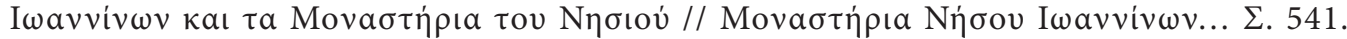

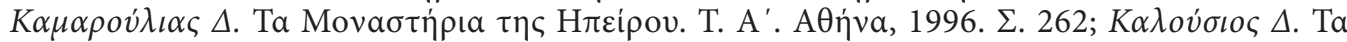

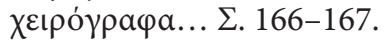

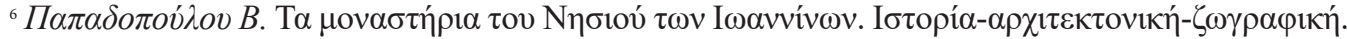

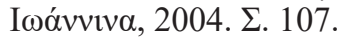

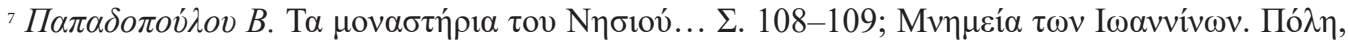

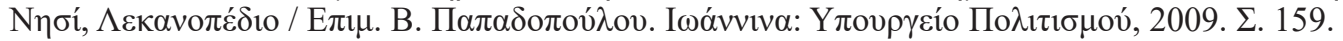

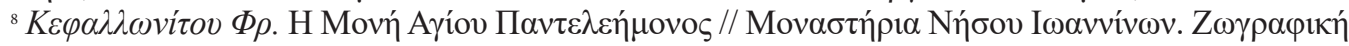

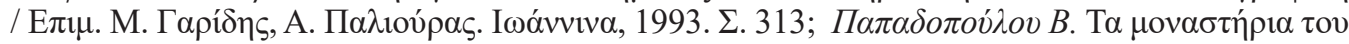

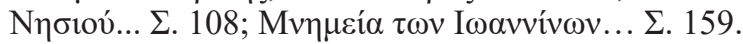

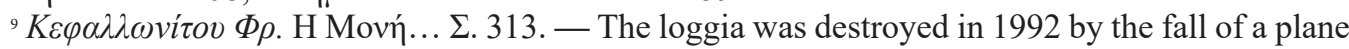
tree and it has been rebuilt. 
The church is built with irregularly placed stones. More elaborate construction is visible on the arch with carved stones in the pseudo-isodomic system and three parallel rows, at approximately equal distances, with local gray stones. On the south wall between the stones are inserted bricks. A brick arched frame is formed above the walled gate ${ }^{10}$.

The wooden iconostasis dates back to the $17^{\text {th }}$ century and its lower parts to the $19^{\text {th }}$ century ${ }^{11}$. Some remarkable icons belong to the monastery, most of which are now in the collection of the metropolis of Ioannina. We should mention an icon with St. Panteleimon $\left(15^{\text {th }} \mathrm{c} .\right)^{12}$, another one with St. Nicholas (c. 1500) ${ }^{13}$ and one more with the enthroned Christ Pantokrator $\left(1^{\text {st }} \text { decade of the } 16^{\text {th }} \mathrm{c} \text {. }\right)^{14}$. Dakaris mentions that a Corinthian capital of a colonnade, decorated with a basket of degenerate thorns and three-leafs, was taken from the monastery ${ }^{15}$.

The fresco decoration of the catholicon is confined to the outer front of the south wall and the lower parts of the sanctuary and the nave (Fig. 4). It is of particular importance, as we distinguish five post-Byzantine phases, the first of which may be dated to the second half of the $15^{\text {th }}$ century ${ }^{16}$ (Fig. 5). The first phase paintings are located in the eastern part of the outer front of the south wall. The rest continue to the west on the outer front of the same wall and on the lower parts inside the church.

From the initial phase, the Deesis can be seen in the lower zone of the southern wall within a frame, from which Christ, $O C \Omega[T H P]$ (the Savior), and on the left

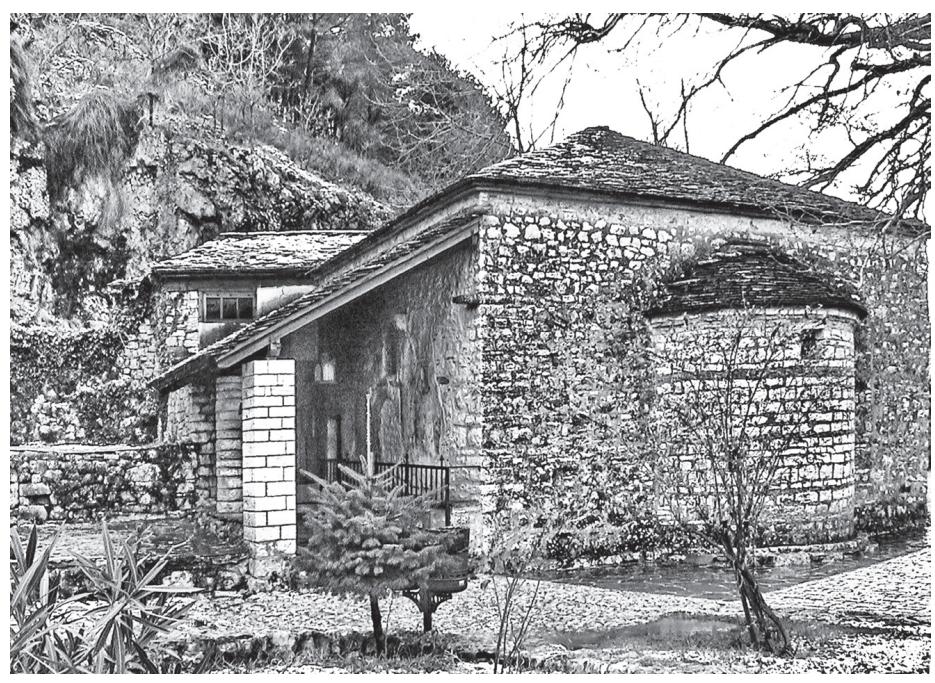

Fig. 2. View of the catholicon from SE. Foto I. P. Chouliarás, 2004 the Virgin Mary (MHP $[\Theta Y]$ ) are preserved (Fig. 6). Christ holds a closed Gospel with his left hand and blesses with his right. The Virgin Mary turns to Christ, passes her left hand in

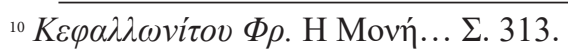

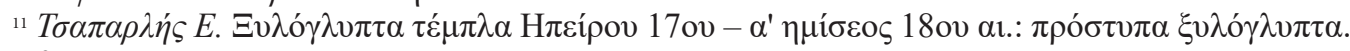

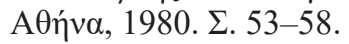

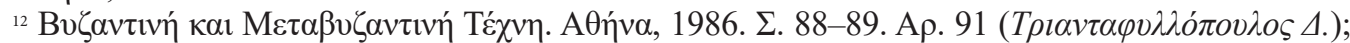
Affreschi e icone dalla Grecia (X-XVII secolo). Atene, 1986. P. 87. Nr 46 (Triantaphyllopoulos D.). ${ }^{13}$ B P. 129. Nr 79 (Triantaphyllopoulos D.).

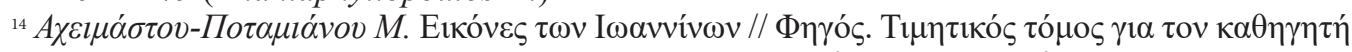

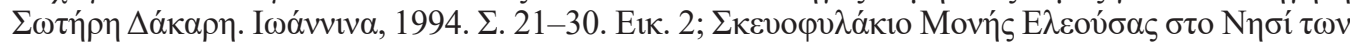
I

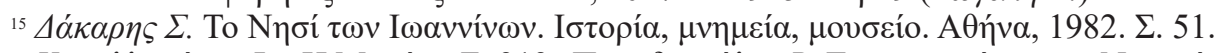

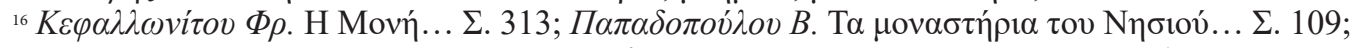

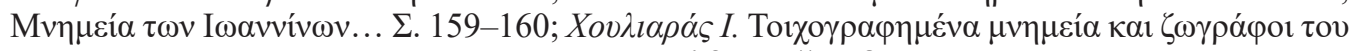

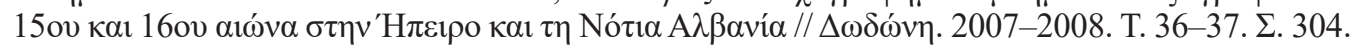




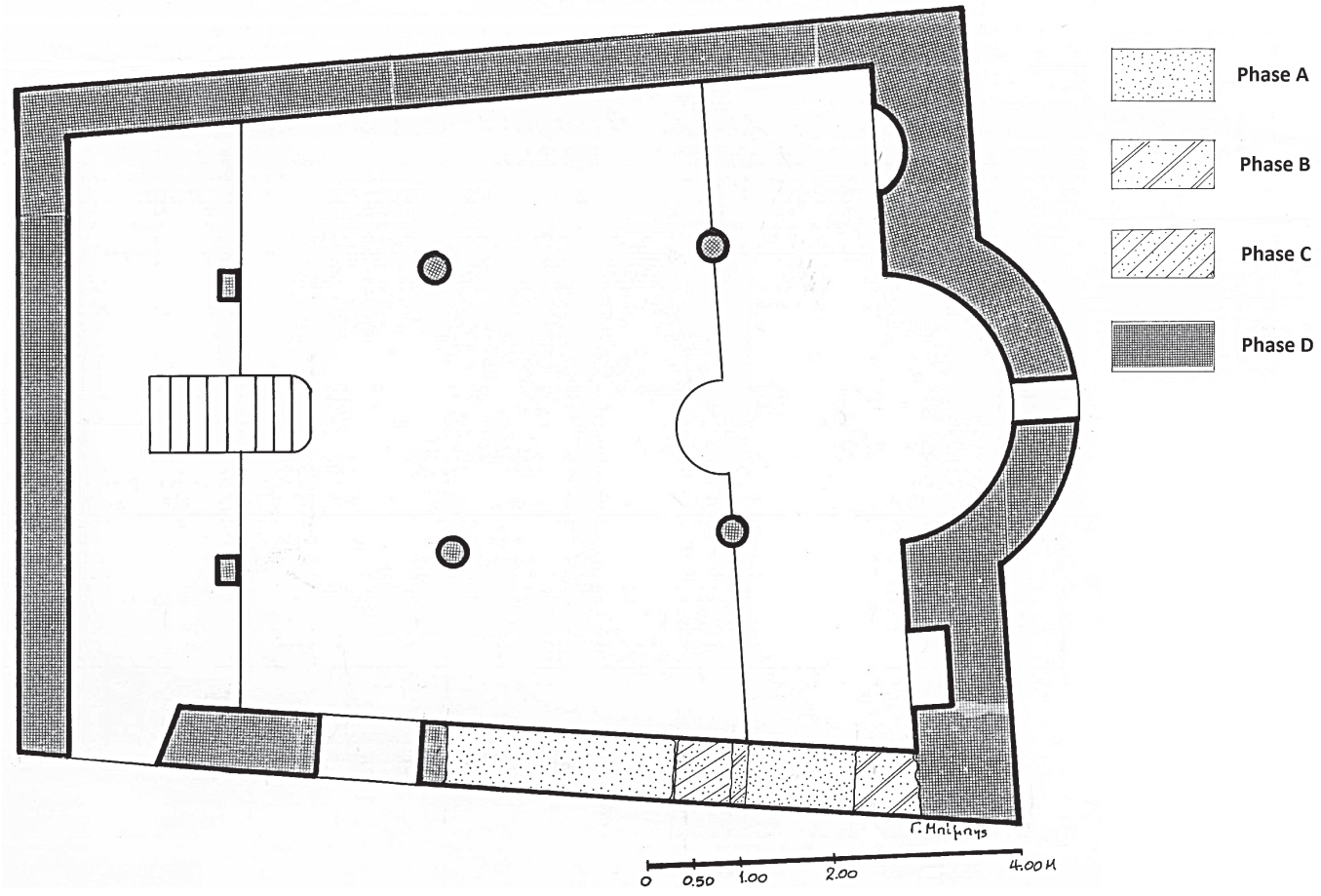

Fig. 3. Groundplan of the catholicon. Archive of the Ephorate of Antiquities of Ioannina

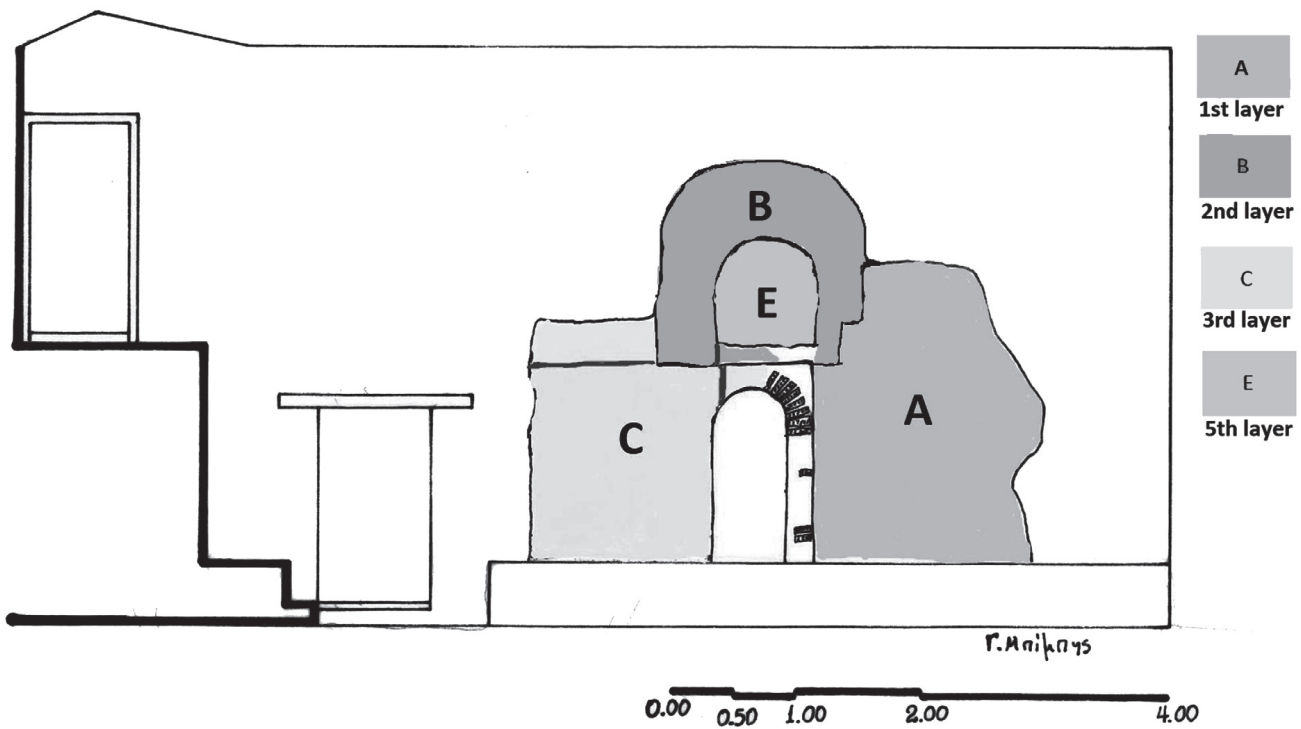

Fig. 4. The painting layers of the south wall. Archive of the Ephorate of Antiquities of Ioannina 
front of her chest and prays with her right. Both figures have probably been repainted from the shoulder and above. Behind the Virgin Mary, St. Nicholas, [O AГIOC] - NIKO/AA[OC], is depicted full-length and frontally, holding a closed Gospel with his left hand and blessing with his right. Above the Deesis, there are three unidentified half-length saints, of whom at least the right one must be a soldier and the middle holds a cross with his raised right hand. To the right of the Deesis a head is visible, probably of an angel, whose position, however, is problematic, as it is depicted exactly next to the closed Gospel of Christ (Fig. 7).

The dress of Christ and the Virgin Mary with chiton and himation reflects conservative patterns of the $14^{\text {th }}$ and mainly of the $15^{\text {th }}$ century in Kastoria and Ohrid ${ }^{17}$. The position of the hands of the Virgin Mary is found in a similar way in Saint George at Kurbinovo (south façade, $1191)^{18}$, in Dečani $(1335-1348)^{19}$, in Christ Zoodotes at Borje of Korytsa $(1389 / 1390)^{20}$ and later in a shrine of the monastery of Megalo Meteoro (1552) ${ }^{21}$. This posture is also characteristic of her representations in the type of the «Paraclesis» in Palaiologan monuments of

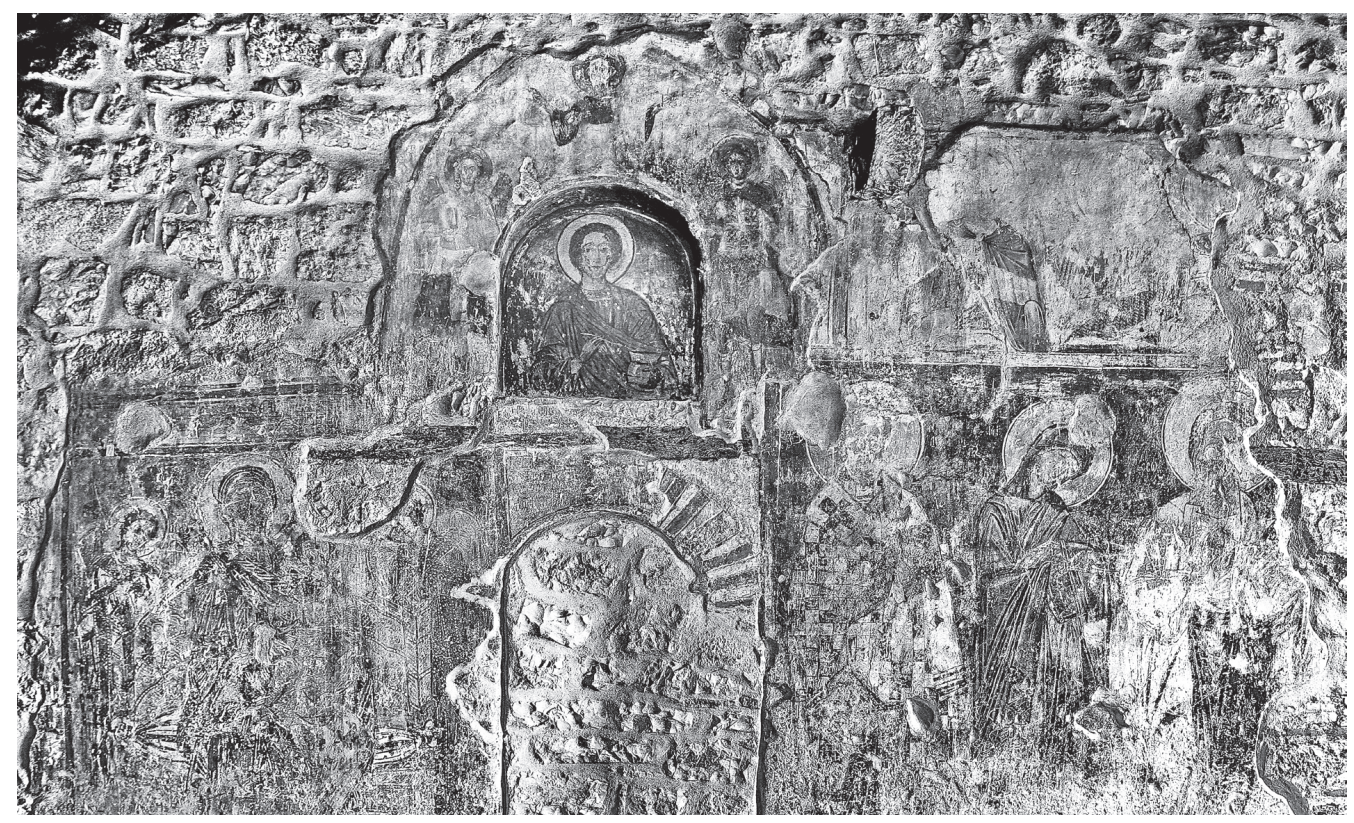

Fig. 5. The decoration of the south wall. Foto I. P. Chouliarás, 2020

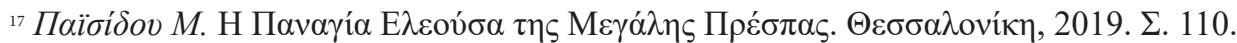

${ }^{18}$ Hadermann-Misguich L. Kurbinovo, Les fresques de Saint-Georges et la peinture byzantine du $\mathrm{XII}^{\mathrm{e}}$ siècle. Bruxelles, 1975. P. 283. Fig. 151, 153.

${ }_{19}$ Radujko M. Fresco Program around the «King's» Throne // Mural Painting of Monastery of Dečani. Material and Studies / Ed. by Vojislav J. Djurić. Beograd, 1995. P. 304-305. Fig. 5.

${ }^{20}$ Lozanova $R$. The Church of Christ Zoodotes in Emborion (Albania) // L'Image et la Parole,

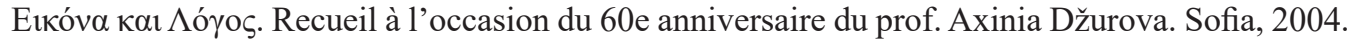

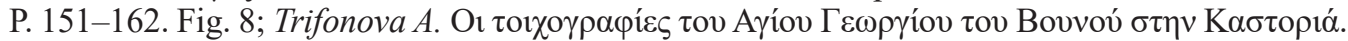

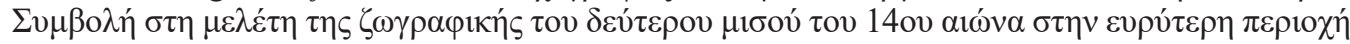

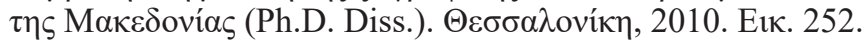

${ }^{21}$ Chatzidakis M., Sofianos D. The Great Meteoron - History and Art. Athens, 1990. P. 182-183. 


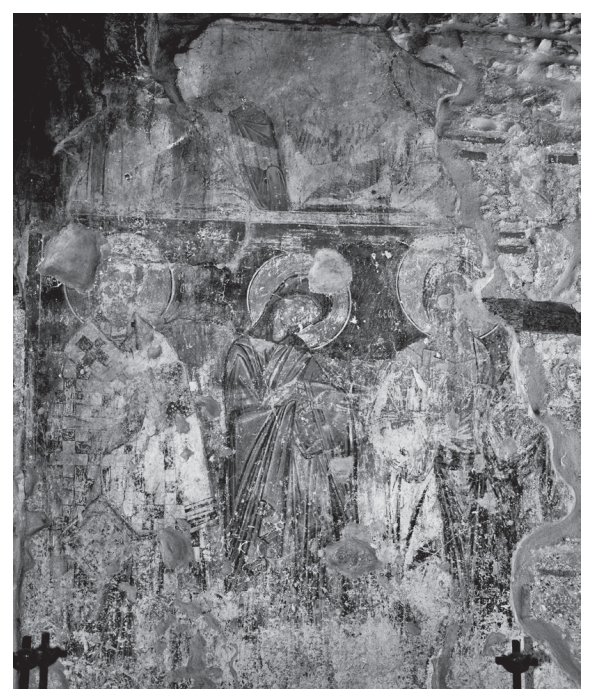

Fig. 6. Deesis, St. Nicholas and saints (first layer). Foto I. P. Chouliarás, 2020

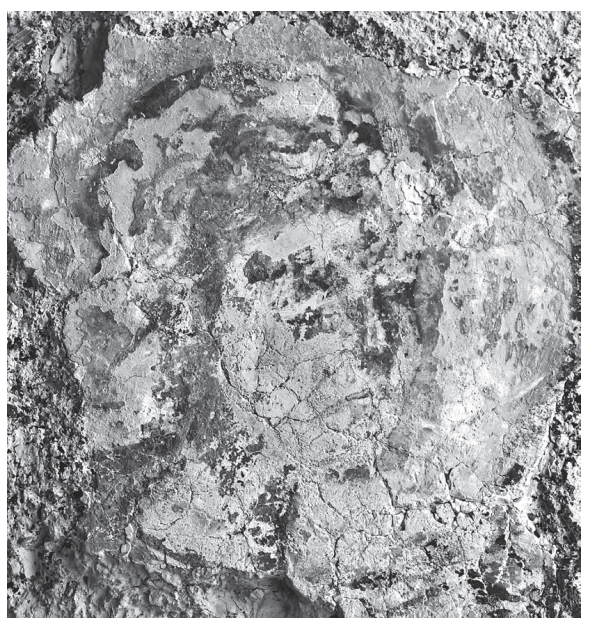

Fig. 7. Head of an angel from the first layer. Foto I. P. Chouliarás, 2020 the wider area of Macedonia, although she holds a scroll there, like in Panagia Olympiotissa at Elasson (late $13^{\text {th }}-$ early $14^{\text {th }}$ c. $)^{22}$, in Saint George at Staro Nagoričino $(1317 / 18)^{23}$, in Lesnovo (1346-1347) ${ }^{24}$, in Agios Nikolaos Tzotza at Kastoria (1360-1380) ${ }^{25}$, etc. The omoforion and felonion of St. Nicholas decorated with crosses are similar to his attire in the Koimisis at Kato Meropi of Pogoni (Epirus) (last decade of the $15^{\text {th }} \mathrm{c}$. $)^{26}$, while the saint participates in the Deesis in the wall paintings of the Monastery of Myrtia in Aetolia (1491) ${ }^{27}$ as well, both works of the painter Xenos Digenis ${ }^{28}$.

The elaborate garments of the Virgin Mary, the colour treatment and the arrangement of the folds of her clothes are reminiscent of the Virgin Mary in the scene of the Annunciation of the Koimisis at Kato Meropi (last decade of the $15^{\text {th }}$ c. $)^{29}$ and the Monastery of Myrtia $(1491)^{30}$, as the dense touches that define the folds are designed in the same way and the overlapping angles of her chiton are formed as it falls from her shoulder. Some of the letters,

${ }^{22}$ Constantinides E. The Wall Paintings of the Panagia Olympiotissa at Elasson in Northern Thessaly. Vol. I. Athens, 1992. P. 213-215. Pl. 60-63, 208a, 210a (with more examples).

${ }^{23}$ Millet G., Frolow A. La peinture du Moyen-âge en Yougoslavie (Serbie, Macédoine et Montenegro). Vol. III. Paris, 1962. P1. 113.1, 113.3.

${ }^{24}$ Gabelić $S$. Manastir Lesnovo, Istorija i slikarstvo. Beograd, 1998. Fig. XLV.

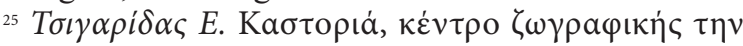

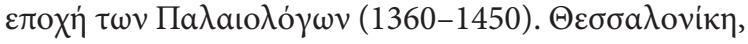
2016. ¿. 93-95. Еıк. 55, 59.

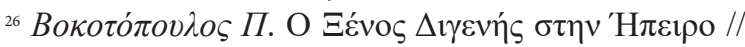

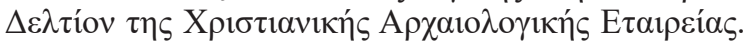
2014. T. 35. $\Sigma$. 176. Eıк. 28.

${ }^{27}$ Agrevi M. The Wall Paintings of Xenos Digenis in the Katholikon of the Myrtia Monastery of Aetolia (1491). The Influence of Cretan Painting on the Work of a Peloponnesian Painter. Leipzig, 2010. P. 113-124. Fig. 28, 29.

${ }^{28}$ For the painter and his artistic career see, $X \alpha \tau \zeta \eta \delta \alpha ́ k \eta \varsigma$

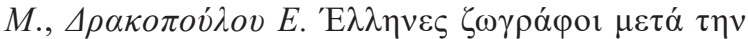

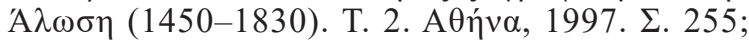
Agrevi M. The Wall Paintings... P. 255-269.

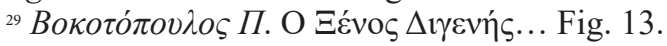

${ }^{30}$ Agrevi M. The Wall Paintings... Fig. 27a-b. 
such as $\langle\mathrm{P} »,\langle\Lambda »$ and $\langle\mathrm{M} »(\mathrm{R}, \mathrm{L}, \mathrm{M})$ also resemble the types of letters of the painter Xenos Digenis in the Koimisis at Kato Meropi and in the Monastery of Myrtia $^{31}$. Of course, it is very difficult to attribute the murals to Xenos Digenis, but they may belong to another gifted artist whose art is very close to that of the painter from Mouchli of Arcadia, yet at the same time it is influenced by the Macedonian Palaiologan tradition.

A second layer of murals is found above the niche of the south wall at the front of the arch of the niche, where Christ is depicted half-length and blessing with open arms (Fig. 8). On either side of the niche there are two full-length archangels who have been partly repainted. Just below the niche, in a narrow frame, there is an illegible inscription today in two rows, with black letters on the white background from which the left part is preserved. Only a few letters are visible: $M N H C[\Theta H] T H K(Y P I) E$ $T \Omega N[. . . / . .$.$] . The inscription seems to be the dedica-$ tory one of this phase. This layer can be dated to the $16^{\text {th }}$ century mainly on the basis of stratigraphy, as it is located above the layer of the $15^{\text {th }}$ century and below that of the next phase (1617/1618). During the same period the upper part of the Deesis of the first layer was probably repainted. However, the location of the scene at the face of an arch and Christ's posture of blessing with open arms is reminiscent of similar depictions of Him for example in Sopoćani (c. 1265) ${ }^{32}$, in the cave of Eleoussa at Ano Myrtia of Aetolia (first half of the $\left.15^{\text {th }} \mathrm{c}.\right)^{33}$ and in the exonarthex of Gračanica $(1570)^{34}$, where Christ is painted in the intrados of an arch blessing the prophets ${ }^{35}$. However, it

${ }_{31}$ Agrevi M. The Wall Paintings... Fig. 8, 10;

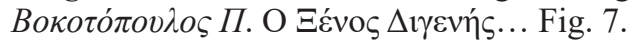

${ }^{32}$ Millet G., Frolow A. La peinture du Moyen-âge en Yougoslavie (Serbie, Macédoine et Montenegro). Vol. II. Paris, 1957. Pl. 30.1.

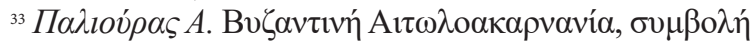

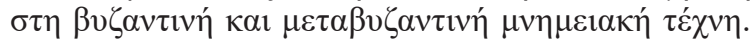
Aүpívio, 2004. Eıк. 59.

${ }^{34}$ Personal observation.

${ }_{35}$ Petković S. Zidno slikarstvo na području Pećke Patrijaršije 1557-1614. Novi Sad, 1965. P. 125. Fig. 42, 43.

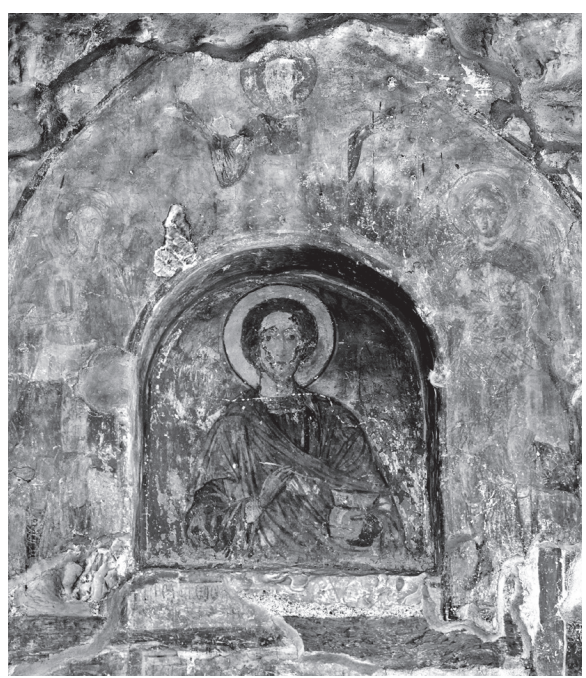

Fig. 8. Christ and Archangels (second layer). St. Panteleimon (fifth layer). Foto I. P. Chouliarás, 2020

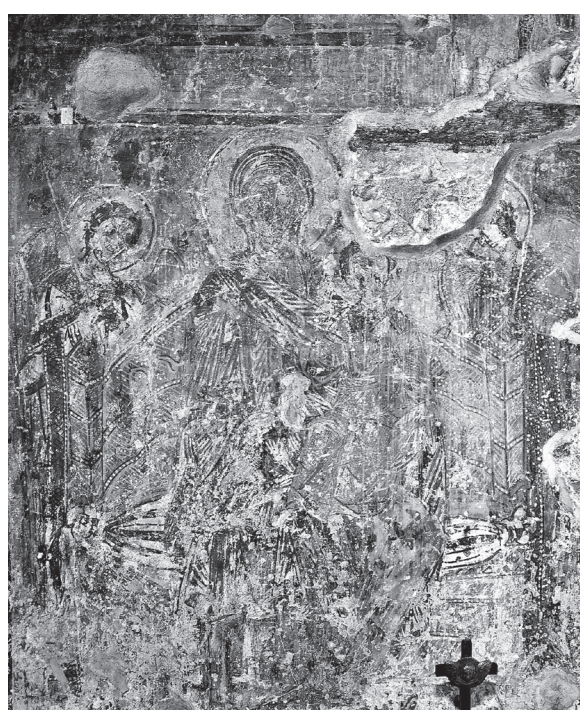

Fig. 9. Enthroned Virgin and angels (third layer). Foto I. P. Chouliarás, 2020 
should be noted that the types of the few letters that are preserved in the dedicatory inscription are reminiscent of those in the icon with the enthroned Christ Pantocrator $\left(1^{\text {st }}\right.$ decade of the $\left.16^{\text {th }} \mathrm{c}.\right)^{36}$.

To the third phase of painting belongs the enthroned Virgin Mary holding the Child amid two angels, pictured behind her massive wooden throne (Fig. 9). The composition is located to the right of the entrance door to the church. To the left of the head of the Virgin Mary one can read the inscription $H Y[\Psi H \Lambda] O / T E[P] A[T \Omega N O Y] P A / N O N$. This layer is precisely dated by an inscription. Above the enthroned Virgin Mary within a triple frame there is a dedicatory inscription in red letters on the green background in two rows, which had not been read until today (Fig. 10) ${ }^{37}$ :

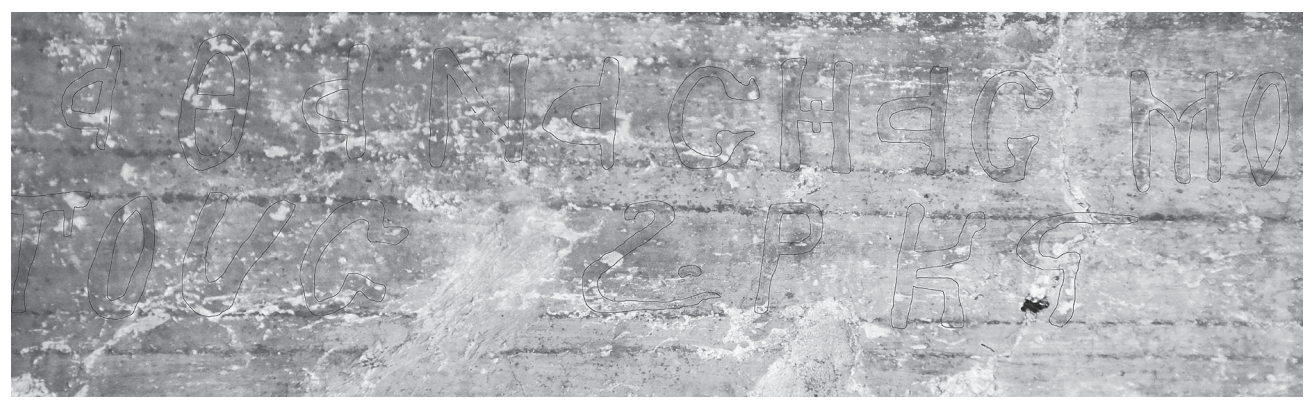

Fig. 10. The dedicatory inscription of the third layer (detail with the date).

Foto I. P. Chouliarás, 2020

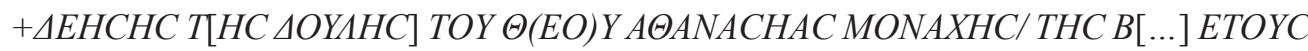 ZPKS (=1617/1618).}

(Deesis of the servant of God Athanasia the nun/ the V[...] year 1617/1618).

Unfortunately, the beginning of the second line is not preserved, where the nickname of the nun may have existed.

Above the walled arched door of the south wall, a liturgical inscription is preserved inside a frame defined by a thick red line with black letters on the white background. The epigram belongs to the same phase as the enthroned Virgin Mary, considering that the letters are similar with those of the dedicatory inscription. This epigram, which also has not been read to date, covers the half of the arch of the walled door and includes the eighth verse of the fifth Psalm:

EГ $\triangle \triangle E[\ldots] /$ EAEOY $(C)$ COY EIC[EAEYCO]/ME EIC TON OIKON [C]OY ПPO[C]/ KOINICO ПРOC NAON [...].

(But I, by your great mercy, will come into your house; in reverence will I bow down toward your holy temple).

This inscription is very important, as it indicates that at least until the $17^{\text {th }}$ century the gate walled today was in use.

The penultimate phase is found only in the interior of the catholicon, in the lower parts of the sanctuary and on the north and south walls of the nave, where a decorative zone, in the

${ }^{36}$ See Fig. 8 and footnote $\mathrm{Nr} 14$.

${ }^{37}$ I would like to thank fr. Gregory Manopoulos for his help in reading the inscription. 
form of a fabric with folds (podea) is distinguished. On the southern wall of the sanctuary, traces of saints, probably hierarchs and a decorative zone in the lower part, are preserved. There is a similar decorative zone in the northeast corner of the sanctuary. The feet of at least

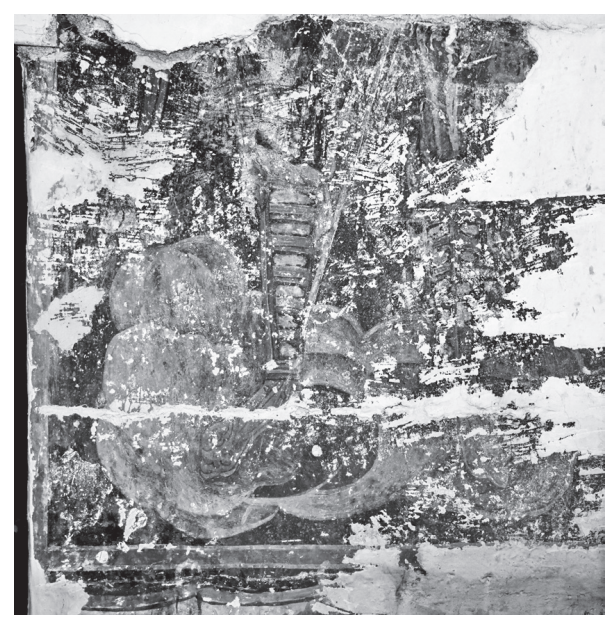

Fig. 11. Archangel Michael. South wall of the nave (forth layer).

Foto I. P. Chouliarás, 2020 two saints are visible on the north wall of the nave, another figure of a saint next to the iconostasis on the south wall and to the right of the doorway to the church there is the lower part of the body of a frontal archangel, probably Michael, who steps on a cloud (Fig. 11). The detail with the realistically rendered cloud, the strict frontality of the archangel and the type of his shoes are similar to icons of the early $18^{\text {th }}$ century ${ }^{38}$. Above the door there should have been an inscription, mentioned by Aravantinos, but not preserved today, and bearing the date $A \Psi Z(=1707)^{39}$.

Aravantinos transcribes it without separating the lines and obviously without keeping the spelling:

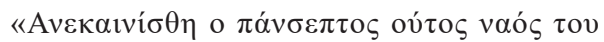

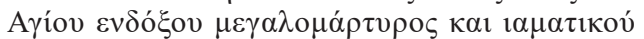

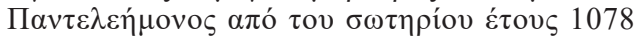

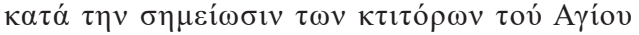

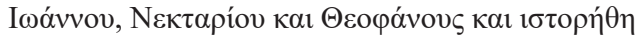

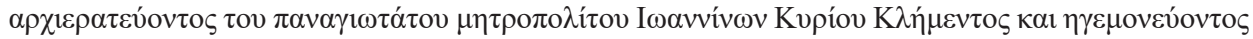

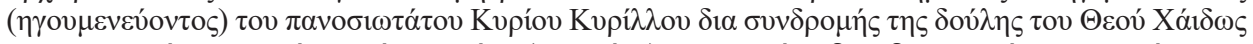

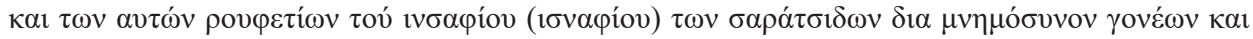

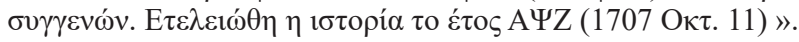

«This pious temple of the glorious great martyr and healer Panteleimon was renovated from the salvation year 1078 according to the note of the founders of Agios Ioannis, Nektarios and Theophanis, and was narrated (painted) during the hierarchy of his holiness the metropolitan of Ioannina $\mathrm{Mr}$ Klimis and during the hegemony (probably: abbotship) of the pious Mr Kyrillos with the assistance of the servant of God Haidos and of the same rufets (guilds) of the insafi (probably: esnaf) of the saratsides for the memorial of parents and relatives. The story (painting) completed the year A $\Psi Z$ (1707 October 11)».

According to the above inscription the penultimate layer is dated to 1707 and this inscription was placed above the new entrance to the catholicon, which replaced the previous one in the middle of the south wall, at the end of the $17^{\text {th }}$ or beginning of the $18^{\text {th }}$ century, after a radical renovation that gave the catholicon its present form. Nektarios and Theophanis were brothers from the Byzantine family of Apsarades, who founded the neighbouring monastery of Agios Ioannis Prodromos ${ }^{40}$. The inscription refers to their autobiography, which mentions the monastery of Agios Panteleimon ${ }^{41}$. In question is the date 1078, as it is for sure a misun-

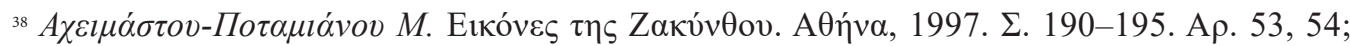

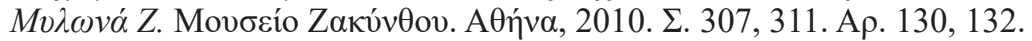

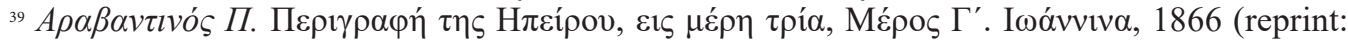

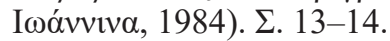

${ }^{40}$ See above in the footnote $\mathrm{Nr} 3$.

${ }^{41}$ See above in the footnote $\mathrm{Nr} 2$. 
derstanding of the year indicated in an earlier inscription. Klimis from the island of Chios (Klimis o Chios) was metropolitan of Ioannina between 1680 and $1715^{42}$ and Kyrillos was the abbot of the monastery. The rufet (esnaf) of the saratsides was a guild with a few members and they were making sandals (saratsika) and equestrian items, but their donation to the monastery shows that they were financially prosperous ${ }^{43}$. Besides, it is known that Ioannina was experiencing great commercial prosperity since the $17^{\text {th }}$ century ${ }^{44}$.

During the late $19^{\text {th }}$ century, the outer conch of the south wall was repainted with St. Panteleimon, who is depicted half-length and holding a vessel and a scalpel (Fig. 8).

The building phases of the catholicon and the multiple layers of its decoration make it one of the most important monuments of the Ioannina area, as it preserves the oldest known frescoes on the Island and throughout the Ioannina basin. Until now the oldest known frescoes on the Island were those of the first layer of the monastery of Philanthropinon (1531/1532) ${ }^{45}$ and in the basin of Ioannina those in Agios Georgios in Kato Lapsista (1508) ${ }^{46}$ and in the church of the Koimisis in Longades (late $15^{\text {th }}-$ early $16^{\text {th }} \mathrm{c}$. $)^{47}$. For the external representation in the outer conch, above the entrance door of the monastery of Philanthropinon, where the archangel Michael is probably depicted, we cannot support any dating, as the fresco is largely extinct today ${ }^{48}$. At the same time, after having read one of the dedicatory inscriptions and the liturgical epigram, it became possible to distinguish more clearly the building phases and the painting layers and to make more effective use of the older reading, by Aravantinos, of the inscription in the interior of the catholicon, which doesn't exist today. The decoration of this monastery is a palimpsest very important for understanding the evolution of the artistic creation on the Island of Ioannina since it includes the painting of five centuries $\left(15^{\text {th }}-19^{\text {th }} \mathrm{c}\right.$. $)$.

\section{Информация о статье}

Автор: Хулиарас, Иоаннис — $\mathrm{PhD}$, директор Охраны памятников Теспротии, Министерство культуры и спорта Греции, Игуменица, Греция; e-mail: ichouliaras@culture.gr

Название: The catholicon of the monastery of Agios Panteleimon on the Island of Ioannina, Greece [Кафоликон монастыря Св. Пантелеимона на острове Янины, Греция]

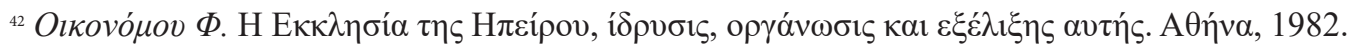
ᄃ. 75 .

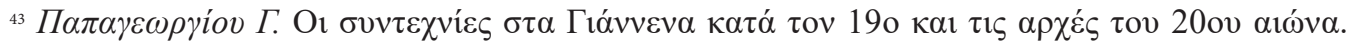

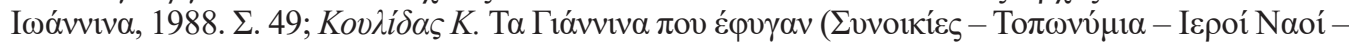

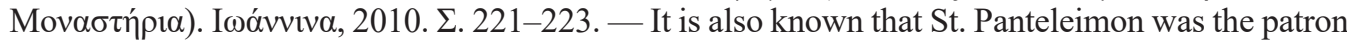
saint of the guild of the tsarouchades (shoemakers) and consequently of all shoe manufacturers.

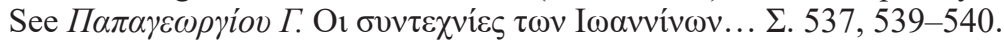

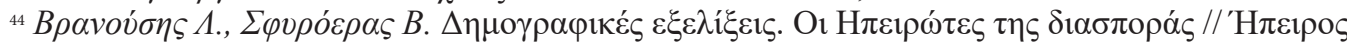

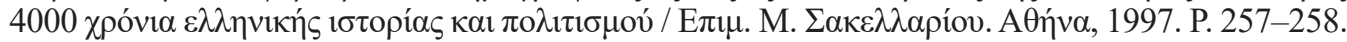

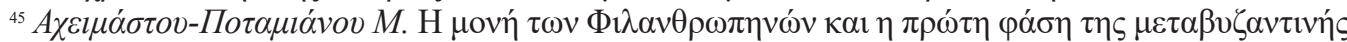

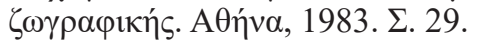

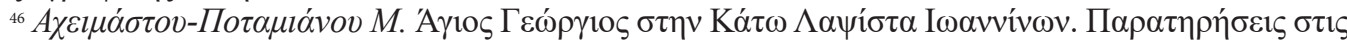

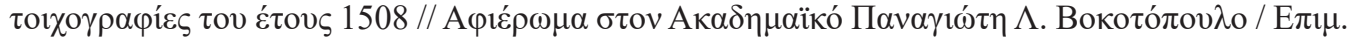

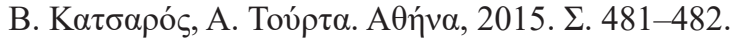

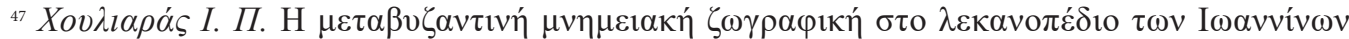

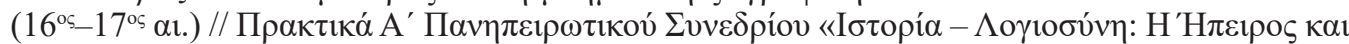

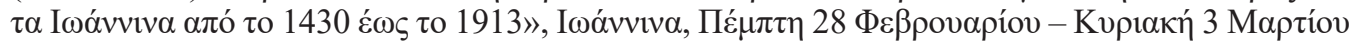

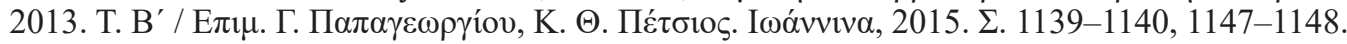

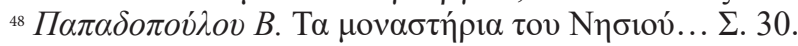


Резюме: Монастырь Св. Пантелеимона расположен в юго-восточной части острова Янины. Он стал широко известен после того, как в одной из его келий в 1822 г. был убит Али Паша. Благодаря исследованию архитектуры и росписи кафоликона стало ясно, что это один из важнейших памятников Янины, поскольку именно здесь находятся самые древние фрески на острове и в регионе в целом. Прочтение одной из посвятительных надписей позволило ясно разделить слои росписи и уточнить данные из второй надписи внутри церквей, опубликованной Аравандиносом.

Кафоликон представляет собой трехнефную базилику с четырехскатной кровлей, свой нынешний масштаб он приобрел в конце XVII или начале XVIII в. Нефы разделяются деревянными столбами. Западная и южная стены (а возможно, и значительная часть восточной) были перестроены после разрушений от обвала камней в начале XIX в. С восточной стороны имеется полукруглая апсида. Первоначально церковь предположительно была небольшой однонефной постройкой с полукруглой апсидой, части которой были обнаружены к юго-востоку от нынешнего храма. В современный храм была включена часть южной стены, оставшаяся от древнейшей постройки начала XV в. С юга в конце XIX в. была добавлена лоджия со скатной кровлей, которая ниже уровня кровли самого храма и, возможно, сменила первоначальную. Опора лоджии принадлежит к более раннему этапу. С запада находится прямоугольный нартекс (вероятно, того же времени, что и лоджия) с четырехскатной кровлей. Нынешний вход в храм расположен в западной части южной стены. Изначально он находился в средней части той же стены, но позднее его замуровали; над замурованной дверью имеется небольшая ниша. Храм построен из камня, с нерегулярной кладкой. Более регулярная кладка апсиды выполнена из тесаных блоков, в псевдо-исодомической технике. На южной стене между камнями вставлены кирпичи, кирпичный архивольт сделан также над замурованной дверью. Росписи сохранились только на внешней стороне южной стены и на нижних частях стен внутри. Они представляют собой немалую ценность и принадлежат к пяти слоям поствизантийского периода, самый старый из которых может быть отнесен к концу XV в. (его фрагменты находятся в восточной части южной стены). Росписи, принадлежащие к следующим слоям, продолжаются на той же стене к западу снаружи и на нижних частях стен внутри. К первоначальной фазе росписи относится Деисус с Христом, Богородицей и фронтальной фигурой св. Николая за ней (верхняя часть композиции переписана). Следующая фаза, которую можно отнести к XVI в., включает полуфигурное изображение Христа, благославляющего обеими руками, над нишей в южной стене; по сторонам от него изображены две фигуры архангелов (эта композиция также поновлялась). К третьему слою росписи относится тронная Богородица с Младенцем и двумя ангелами, стоящими за массивной спинкой ее деревянного престола. Сцена находится справа от входа в храм. Этот слой может быть датирован по посвятительной надписи, в которой указан год $Z P K C$ (= 1617/18). Предпоследний слой росписи находится только внутри церкви - в нижних частях алтаря и боковых стен, где сохранились декоративные мотивы. На южной стене сохранилось изображение ног по меньшей мере двух святых, а также одна фигура рядом с иконостасом и нижняя часть фигуры архангела на облаке (справа от входа в храм). Над дверью была помещена надпись 1707 года, упоминаемая Аравандиносом, и ныне утраченная. В конце XIX в. в нише на южном фасаде было написано полуфигурное изображение св. Пантелеимона, держащего в руках скальпель и сосуд.

Ключевые слова: монастырь Св. Пантелеимона, Остров Янины, Янина, поствизантийская живопись, Ксенос Дигенис, Нектарий и Феофан Апсарады, искусство, история культуры

\section{Список использованной литературы:}

Acheimastou-Potamianou, Myrtalē. $\overline{\mathrm{E}}$ monē tōn Philanthrōpēnōn kai è prōtē phasē tēs metabyzantinēs zōgraphikēs. Athēna: Adam, 1983. 286 p.

Acheimastou-Potamianou, Myrtalē. Eikones tēs Zakynthou. Athēna: Iera Mētropoli s Zakynthou kai Strophadōn, 1997. 290 p.

Acheimastou-Potamianou, Myrtalē. Eikones tōn Iōanninōn // Phēgos. Timētikos tomos gia ton kathēgētē Sōtērē Dakarē. Iōannina: Panepistēmio Iōanninōn, 1994. P. 21-30.

Acheimastou-Potamianou, Myrtalē. Agios Geōrgios stēn Katō Lapsista Iōanninōn. Paratērēseis stis toichographies tou etous 1508 // Aphierōma ston Akadēmaiko Panagiōtē L. Vokotopoulo / Epim. Katsaros, Basilis; Tourta, Anastasia. Athēna: Ekdoseis Kapon, 2015. P. 481-490.

Affreschi e icone dalla Grecia (X-XVII secolo). Athēna: Museo bizantino di Atene, 1986. 159 p.

Agoritsas, Dēmētrios. Bios kai Politeia tōn osiōn Nektariou kai Theophanous tōn Apsaradōn. Agia Meteōra: Iera monē Barlaam, 2018. 382 p. 
Agrevi, Maria. The Wall Paintings of Xenos Digenis in the Katholikon of the Myrtia Monastery of Aetolia (1491). The Influence of Cretan Painting on the Work of a Peloponnesian Painter. Leipzig: Eudora-Verlag, 2010. 352 p.

Aravantinos, Panagiōtēs. Perigraphē tēs Ēpeirou, eis merē tria. Iōannina: Etaireia Ēpeirōtikōn Meletōn, 1984. $997 \mathrm{p}$.

Aravantinos, Panagiōtēs. Istoria Alē Pasa tou Tepelenlē. Athēna: Typographeio S. Kousoulinou, 1895. 613 p. Athēnagoras, Mētropolitēs Paramythias kai Pargas. Neos Koubaras // Ēpeirōtika Chronika. 1929. T. 4. P. $1-54$.

Byzantinē kai Metabyzantinē Technē. Athēna: Tameio Archaiologikōn Porōn, 1986. 265 p.

Chatzidakis, Manolis; Drakopoulou, Eugenia. Ellēnes zōgraphoi meta tēn Alōsēe (1450-1830). T. 2. Athēna:

Kentro Neoellēnikōn Ereunōn, 1997. 474 p.

Chatzidakis, Manolis; Sofianos, Dimitrios. The Great Meteoron - History and Art. Athens: Interamerican, 1990. 222 p.

Chouliaras, Iōannēs. Toichographēmena mnēmeia kai zōgraphoi tou 15ou kai 16ou aiōna stēn Ēpeiro kai tē Notia Albania // Dōdōnē. 2007-2008. T. 36-37. P. 295-332.

Chouliaras, Iōannēs. Ē metabyzantinē mnēmeiakē zōgraphikē sto lekanopedio tōn Iōanninōn (16os-17os ai.) // Praktika A Panēpeirōtikou Synedriou «Istoria - Logiosynē: Ē Ēpeiros kai ta Iōannina apo to 1430 eōs to 1913», Iōannina, Pemptē 28 Fevrouariou - Kyriakē 3 Martiou 2013 / Ed. Papageōrgiou, Georgios; Petsios, Konstantinos Th. Vol. 2. Iōannina: Panepistēmio Iōanninōn, 2015. P. 1139-1148.

Constantinides, Efthalia. The Wall Paintings of the Panagia Olympiotissa at Elasson in Northern Thessaly. Vol. I. Athens: Canadian Archaeological Institute at Athens, 1992. $401 \mathrm{p}$.

Dakarēs, Sōtērēs. To Nēsi tōn Iōanninōn. Istoria, mnēmeia, mouseio. Athēna: Tolidēs, 1982. 85 p.

Gabelić, Smiljka. Manastir Lesnovo, Istorija i slikarstvo. Beograd: Stubovi kulture, 1998. 305 p.

Hadermann-Misguich, Lydie. Kurbinovo, Les fresques de Saint-Georges et la peinture byzantine du XII ${ }^{\mathrm{e}}$ siècle. Bruxelles: Editions de Byzantion, 1975. 606 p.

Kalousios, Dēmètrios. Ta cheirographa tēs Bylizas: Iera Monē tou Euangelismou tēs Theotokou sto Matsouki Iōanninōn. Matsouki Iōanninōn: Monastēriakē Epitropē Ieras Monēs Bylizas, 2009. 334 p.

Kamaroulias, Dēmētrios. Ta Monastēria tēs Ēpeirou. T. 1. Athēna: Mpastas - Plessas, 1996. 665 p.

Kephallōnitou, Phrankiska. Ē Monē Agiou Panteleēmonos [Monastery of Saint Panteleimon] // Monastēria Nēsou Iōanninōn. Zōgraphikē / Epim. Garidēs, Miltos; Paliouras, Athanasios. Iōannina: Mētropolē Iōannēnōn, 1993. P. 313.

Koulidas, Kōnstantinos. Ta Giannina pou ephygan (Synoikies — Topōnymia — Ieroi Naoi — Monastēria). Iōannina: Idiōtikē ekdosē, 2010. 440 p.

Lampros, Spyridōn. Symbolai eis tēn istorian tōn monōn tōn Meteōrōn // Neos Ellēnomnēmōn. 1905. T. 2 (A). P. 49-156.

Lozanova, Ralitsa. The Church of Christ Zoodotes in Emborion (Albania) // L'Image et la Parole, Eıkóva

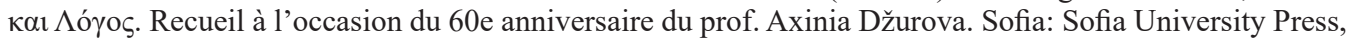
2004. P. 151-162.

Mertzios, Kōnstantinos. To en Benetia Ëpeirōtikon Archeion // Ēpeirōtika Chronika. 1936. T. 11. P. 1-352. Millet, Gabriel; Frolow, Anatole. La peinture du Moyen-âge en Yougoslavie (Serbie, Macédoine et Montenegro). Vol. II. Paris: E. de Boccard, 1957. 13 p., 103 pl.; Vol. III. Paris: E. de Boccard, 1962. 24 p., $64 \mathrm{pl}$.

Mnēmeia tōn Iōanninōn. Polē, Nēsi, Lekanopedio / Epim. Papadopoulou, Varvara N. Iōannina: Ypourgeio Politismou, 2009. $196 \mathrm{p}$.

Mylōna, Zōē. Mouseio Zakynthou. Athēna: Ypourgeio Politismou kai Tourismou, 2010. 507 p.

Oikonomou, Phōtios. Ē Ekklēsia tēs Ēpeirou, idrysis, organōsis kai exelixēs autēs. Athēna: Idiōtikē ekdosē, 1982. $328 \mathrm{p}$.

Paisidou, Melachroinēe. Ē Panagia Eleousa tēs Megalēs Prespas. Thessalonikē: Etaireia Makedonikōn Spoudōn, 2019. 238 p.

Paliouras, Athanasios. Byzantinē Aitōloakarnania, symbolē stē byzantinē kai metabyzantinē mnēmeiakē technē. Agrinio: Iphitos, 2004. 450 p.

Papadopoulou, Varvara. Ta monastēria tou Nēsiou tōn Iōanninōn. Istoria — architektonikē — zōgraphikē. Iōannina: Iera monē Eleousēs Nēsou, 2004. 107 p.

Papageōrgiou, Giōrgos. Oi syntechnies sta Giannena kata ton 19o kai tis arches tou 20ou aiōna. Iōannina: Panepistēmio Iōanninōn, 1988. 368 p. 
Papageōrgiou, Giōrgos. Oi syntechnies ton Ioanninon kai ta Monastēria tou Nēsiou, in Monastēria Nēsou Iōanninōn // Praktika Symposiou: 700 chronia 1292-1992 (29-31 Maiou 1992) / Ed. Garidēs, Miltos; Paliouras, Athanasios. Iōannina: Panepistēmio Iōanninōn, 1999. P. 535-546.

Petković, Sreten. Zidno slikarstvo na području Pećke Patrijaršije 1557-1614. Novi Sad: Matica srpska, 1965. $361 \mathrm{p}$.

Radujko, Milan. Fresco Program around the «King's» Throne // Mural Painting of Monastery of Dečani. Material and Studies / Ed. by Vojislav J. Djurić. Beograd, 1995. P. 301-307.

Sarros, Dēmētrios. Ēpeirōtikai enthymēseis è chronika sēmeiōmata kai epigraphai // Ēpeirōtika Chronika. 1937. T. 12. P. 104-132.

Skeuophylakio Monēs Eleousas sto Nēsi tōn Iōanninōn. Oi phorētes eikones. Iōannina: Ypourgeio politismou kai athlētismou, Ephoreia archaiotētōn Iōanninōn, 2017. 141 p.

Tourta, Anastasia. Monē Prodromou Nēsou Iōanninōn. Oi Apsarades kai ta idrymata tous // Monastēria Nēsou Iōanninōn, Praktika Symposiou: 700 chronia 1292-1992 (29-31 Maiou 1992) / Ed. Garidēs, Miltos; Paliouras, Athanasios. Iōannina: Panepistēmio Iōanninōn, 1999. P. 343-355.

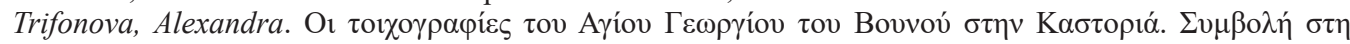

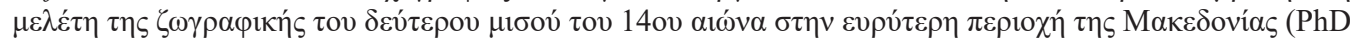

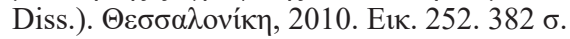

Tsaparlēs, Eustratios. Xyloglypta templa Ēpeirou $17 \mathrm{ou}$ - a' ēmiseos $18 \mathrm{ou}$ ai.: prostypa xyloglypta. Athēna: Panepistēmio Athēnōn, 1980. 182 p.

Tsigaridas, Euthymios. Kastoria, kentro zōgraphikēs tēn epochē tōn Palaiologōn (1360-1450). Thessalonikē: Etaireia Makedonikōn Spoudōn, 2016. 631 p.

Vokotopoulos, Panagiōtēs. O Xenos Digenēs stēn Ēpeiro // Deltion tēs Christianikēs Archaiologikēs Etaireias. 2014. T. 35. P. 143-182.

Vranousēs, Leandros; Sphyroeras, Vasileios. Dēmographikes exelixeis. Oi Ēpeirōtes tēs diasporas // Ēpeiros. 4000 chronia ellēnikēs istorias kai politismou / Epim. M. Sakellariou. Athēna: Ekdotikē Athēnōn, 1997. P. 257-264.

\section{Information about the article}

Author: Chouliarás, Ioannis P. - PhD, Director, Ephorate of Antiquities of Thesprotia, Ministry of Culture and Sports, Igoumenitsa, Greece; e-mail: ichouliaras@culture.gr

Title: The catholicon of the monastery of Agios Panteleimon on the Island of Ioannina, Greece

Summary: The monastery is located at the SE end of the settlement of the Island and became widely known in modern history, as Ali Pasha was assassinated in its cells in 1822. The catholicon today is a three-aisled basilica with a quadruple roof and in its present size was probably built at late $17^{\text {th }}$ or early $18^{\text {th }}$ century. The aisles are separated by wooden colonnades. The $\mathrm{W}$ and $\mathrm{N}$ walls, probably most of the $\mathrm{E}$, were rebuilt after their destruction in the early $19^{\text {th }}$ century by falling rocks. In the E there is a semicircular arch. The original church was supposed to be a small one-aisled with a semicircular arch, traces of which were discovered on the SE side of the modern church. From the early building phase the modern church has incorporated part of the $\mathrm{S}$ wall, which dates to the early $15^{\text {th }}$ century. On the $\mathrm{W}$ side was added a late $19^{\text {th }}$ century loggia, which is roofed with a sloping roof lower than that of the church and possibly replaced an older one. The column of the loggia comes from an earlier building phase of the church. On the W side is raised a rectangular narthex, possibly of the same date as the loggia, which is roofed with a quadruple roof. The present entrance door to the main church is located at the $\mathrm{W}$ end of the $\mathrm{S}$ wall, while the original door was opened in the middle of the same wall and has been walled today. There is a small conch above the walled door. The church is built of stone with irregularly placed stones. More elaborate construction on the arch with carved stones in the pseudo-isodomic system. On the $\mathrm{S}$ wall between the stones are inserted bricks. Brick arched frame is formed above the walled gate. The fresco decoration of the catholicon is confined to the outer front of the $\mathrm{S}$ wall and the lower parts of the main church. It is of particular importance, as we distinguish five post-Byzantine phases, the first of which at the end of the $15^{\text {th }}$ century. The first is located in the $\mathrm{E}$ part of the outer front of the $\mathrm{S}$ wall. The rest continue to the $\mathrm{W}$ on the outer front of the same wall and on the lower parts inside the main church. In the initial phase of the frescoes belong the Deisis with the Christ and the Virgin, as well as the frontal St. Nicholas, behind the Virgin. The upper parts of the scene have been repainted. The next phase, which can be dated to the $16^{\text {th }}$ century, involves the half-bodied Christ above the conch of the $\mathrm{S}$ wall, who blesses with open arms and two full-length archangels on either side of the conch, who have also been repainted. In the third phase 
of the painting belongs the enthroned Virgin holding the Child amid two angels, pictured behind her massive wooden throne. The composition is to the right of the entrance door to the church. This layer is precisely dated by a dedicatory inscription bearing the date $Z P K \subseteq(=1617 / 18)$. The penultimate phase is found only in the interior of the catholicon, in the lower parts of the sanctuary, and on the $\mathrm{N}$ and $\mathrm{S}$ walls of the main church, where a decorative zone is distinguished. The feet of at least two saints are visible on the $\mathrm{N}$ wall, another figure of saint next to the iconostasis on the $\mathrm{S}$ wall and to the right of the doorway to the church the lower part of the body of a frontal archangel, who steps on a cloud. Above the door there should have been the inscription, mentioned by Aravantinos, but not preserved today, and bearing the date $A \Psi Z(=1707)$. During the late $19^{\text {th }}$ century, the outer conch of the $\mathrm{S}$ wall was painted with St. Panteleimon, who is depicted half-bodied and holding a vessel and a scalpel. The building phases of the catholicon and the multiple layers of its decoration make it one of the most important monuments of the Ioannina area, as it locates the oldest known frescoes on the Island and throughout the Ioannina basin. At the same time, after reading of one of the dedicatory inscriptions, it was possible to distinguish more clearly the painting layers and to make more effective use of the older reading, by Aravantinos, of the inscription in the interior of the catholicon.

Keywords: Monastery of Agios Panteleimon, the Island of Ioannina, Ioannina, post-Byzantine painting,

Xenos Digenis, Nektarios and Theophanis Apsarades, art, cultural studies

\section{References:}

Acheimastou-Potamianou, Myrtalē. E monē tōn Philanthrōpēnōn kai ē prōtē phasē tēs metabyzantinēs zögraphikēs [The Monastery of Philanthropinon and the first Phase of its Postbyzantine Painting]. Athens: Adam Publ., 1983. 286 p. (in Greek).

Acheimastou-Potamianou, Myrtalē. Eikones tēs Zakynthou [Icons of Zakynthos]. Athens: Iera Mētropolis Zakynthou kai Strophadōn Publ., 1997. 290 p. (in Greek).

Acheimastou-Potamianou, Myrtalē. Eikones tōn Iōanninōn [Icons of Ioannina], in Phēgos. Timētikos tomos gia ton kathègètē Sōtērē Dakarē [St. George in Kato Lapsista of Ioannina. Notes on the Frescoes of 1508]. Ioannina: Panepistēmio Iōanninōn Publ., 1994. Pp. 21-30. (in Greek).

Acheimastou-Potamianou, Myrtalē. Agios Geōrgios stēn Katō Lapsista Iōanninōn. Paratērēseis stis toichographies tou etous 1508, in Katsaros, Basilis; Tourta, Anastasia (eds). Aphierōma ston Akadēmaiko Panagiōtē L. Vokotopoulo. Athens: Ekdoseis Kapon Publ., 2015. Pp. 481-490. (in Greek).

Affreschi e icone dalla Grecia (X-XVII secolo) [Frescoes and icons from Greece (1 $10^{\text {th }}-17^{\text {th }}$ centuries)]. Athens: Museo bizantino di Atene Publ., 1986. 159 p. (in Italian).

Agoritsas, Dēmētrios. Bios kai Politeia tōn osiōn Nektariou kai Theophanous tōn Apsaradōn [Life and activities of saints Nektarios and Theophanes Apsarades]. Agia Meteora: Iera monē Barlaam Publ., 2018. 382 p. (in Greek).

Agrevi, Maria. The Wall Paintings of Xenos Digenis in the Katholikon of the Myrtia Monastery of Aetolia (1491). The Influence of Cretan Painting on the Work of a Peloponnesian Painter. Leipzig: Eudora-Verlag Publ., 2010. 352 p.

Aravantinos, Panagiōtēs. Perigraphē tēs Ēpeirou, eis merē tria [Description of Epirus in three parts]. Ioannina: Etaireia Ëpeirōtikōn Meletōn Publ., 1984. 997 p. (in Greek).

Aravantinos, Panagiōtēs. Istoria Alē Pasa tou Tepelenlē [History of Ali Pasha Tepelenli]. Athens: Typographeio S. Kousoulinou Publ., 1895. 613 p. (in Greek).

Athēnagoras, Mētropolitēs Paramythias kai Pargas. Neos Koubaras, in Ēpeirōtika Chronika. 1929. Vol. 4. Pp. 1-54. (in Greek).

Byzantinē kai Metabyzantinē Technē [Byzantine and Postbyzantine art]. Athens: Tameio Archaiologikōn Porōn Publ., 1986. 265 p. (in Greek).

Chatzidakis, Manolis; Drakopoulou, Eugenia. Ellēnes zōgraphoi meta tēn Alōsē (1450-1830) [Greek painters after the Fall of Constantinople (1450-1830)]. T. 2. Athens: Kentro Neoellēnikōn Ereunōn Publ., 1997. 474 p. (in Greek).

Chatzidakis, Manolis; Sofianos, Dimitrios. The Great Meteoron - History and Art. Athens: Interamerican Publ., 1990. 222 p.

Chouliaras, Iōannēs. Toichographēmena mnēmeia kai zōgraphoi tou 15ou kai 16ou aiōna stēn Ēpeiro kai tē Notia Albania [Fresco ensembles and painters of the $15^{\text {th }}$ and $16^{\text {th }}$ centuries in Epirus and South Apbania], in Dōdōnē. 2007-2008. Vol. 36-37. Pp. 295-332. (in Greek).

Chouliaras, Iōannēs. Ē metabyzantinē mnēmeiakē zōgraphikē sto lekanopedio tōn Iōanninōn (16os17os ai.), in Papageōrgiou, Georgios; Petsios, Konstantinos Th. (eds). Praktika A Panēpeirōtikou Synedriou «Istoria - Logiosynē: É Épeiros kai ta Ióannina apo to 1430 eōs to 1913», Iōannina, 
Pemptē 28 Fevrouariou - Kyriakē 3 Martiou 2013. Vol. 2. Ioannina: Panepistēmio Iōanninōn Publ., 2015. Pp. 1139-1148. (in Greek).

Constantinides, Efthalia. The Wall Paintings of the Panagia Olympiotissa at Elasson in Northern Thessaly. Vol. I. Athens: Canadian Archaeological Institute at Athens Press, 1992. 401 p.

Dakarēs, Sōtērēs. To Nēsi tōn Iōanninōn. Istoria, mnēmeia, mouseio [The Island of Ioannina. History, monuments, museum]. Athens: Tolidēs Publ., 1982. 85 p. (in Greek).

Gabelić, Smiljka. Manastir Lesnovo, Istorija i slikarstvo [Lesnovo Monastery, History and Painting]. Belgrade: Stubovi kulture Publ., 1998. 305 p. (in Serbian).

Hadermann-Misguich, Lydie. Kurbinovo, Les fresques de Saint-Georges et la peinture byzantine du XII' siècle [Kurbinovo, the frescoes of St. George and the $12^{\text {th }}$ century Byzantine painting]. Brussels: Editions de Byzantion Publ., 1975. 606 p. (in French).

Kalousios, Dēmētrios. Ta cheirographa tēs Bylizas: Iera Monè tou Euangelismou tēs Theotokou sto Matsouki Iōanninōn [The manuscripts of Bylizas: The Holy monastery of Annunciation of Mother of God at Matsouki Ioanninon]. Matsouki Ioanninon: Monastēriakē Epitropē Ieras Monēs Bylizas Publ., 2009. 334 p. (in Greek). Kamaroulias, Dēmētrios. Ta Monastēria tēs Ėpeirou [Monasteries of Epirus]. Vol. 1. Athens: Mpastas Plessas Publ., 1996. 665 p. (in Greek).

Kephallōnitou, Phrankiska. $\overline{\mathrm{E}}$ Monē Agiou Panteleēmonos [Monastery of Saint Panteleimon], in Garidēs, Miltos; Paliouras, Athanasios (eds). Monastēria Nēsou Iōanninōn. Zōgraphikē [Monasteries of the Island of Ioannina]. Ioannina: Mētropolē Iōannēnōn Publ., 1993. P. 313. (in Greek).

Koulidas, Kōnstantinos. Ta Giannina pou ephygan (Synoikies - Topōnymia - Ieroi Naoi - Monastēria) [The Bygone Ianinna. Neighborhoods - Toponyms - Churches - Monasteries]. Ioannina: Idiōtikē ekdosē Publ., 2010. 440 p. (in Greek).

Lampros, Spyridōn. Symbolai eis tēn istorian tōn monōn tōn Meteōrōn [Contribution to the history of Meteora Monasteries], in Neos Ellēnomnēmōn. 1905. Vol. 2 (A). Pp. 49-156. (in Greek).

Lozanova, Ralitsa. The Church of Christ Zoodotes in Emborion (Albania), in L'Image et la Parole, Elkóva кal Aóyos. Recueil à l'occasion du 60e anniversaire du prof. Axinia Džurova. Sofia: Sofia University Press, 2004. Pp. 151-162.

Mertzios, Kōnstantinos. To en Benetia Ëpeirōtikon Archeion [The Epirote Archive in Venice], in Épeirōtika Chronika. 1936. Vol. 11. Pp. 1-352. (in Greek).

Millet, Gabriel; Frolow, Anatole. La peinture du Moyen-âge en Yougoslavie (Serbie, Macédoine et Montenegro) [Medieval painting in Yugoslavia (Serbia, Macedonia and Montenegro)]. Vol. II. Paris: E. de Boccard Publ., 1957. 13 p., 103 pl.; Vol. III. Paris: E. de Boccard Publ., 1962. 24 p., 64 pl. (in French). Mylōna, Zōē. Mouseio Zakynthou [Zakynthos Museum]. Athens: Ypourgeio Politismou kai Tourismou Publ., 2010. 507 p. (in Greek).

Oikonomou, Phōtios. É Ekklēsia tēs Ēpeirou, idrysis, organōsis kai exelixēs autēs [Church of Epirus. Foundation, organization and development]. Athens: Idiōtikē ekdosē Publ., 1982. 328 p. (in Greek).

Paisidou, Melachroinē. É Panagia Eleousa tēs Megalès Prespas [Panagia Eleusa of the Great Prespa]. Thessaloniki: Etaireia Makedonikōn Spoudōn Publ., 2019. 238 p. (in Greek).

Paliouras, Athanasios. Byzantinē Aitōloakarnania, symbolē stē byzantinē kai metabyzantinè mnēmeiakē technē [Byzantine Aitoloakarnania. Contribution to its Byzantine and Postbyzantine monumental art]. Agrinio: Iphitos Publ., 2004. 450 p. (in Greek).

Papadopoulou, Varvara N. (ed.). Mnēmeia tōn Iōanninōn. Polē, Nēsi, Lekanopedio [Monuments of Ioannina. The City, the Island, the Basin]. Ioannina: Ypourgeio Politismou Publ., 2009. 196 p. (in Greek).

Papadopoulou, Varvara. Ta monastēria tou Nēsiou tōn Iōanninōn. Istoria - architektonikē — zōgraphikē [Monasteries of the Ioannina Island. History — architecture — painting]. Ioannina: Iera monē Eleousēs Nēsou Publ., 2004. 107 p. (in Greek).

Papageōrgiou, Giōrgos. Oi syntechnies sta Giannena kata ton 19o kai tis arches tou 20ou aiōna [The Guilds in Ioannina in the $19^{\text {th }}$ and the early 20 $0^{\text {th }}$ century]. Ioannina: Panepistēmio Iōanninōn Publ., 1988. 368 p. (in Greek).

Papageōrgiou, Giōrgos. Oi syntechnies ton Ioanninon kai ta Monastēria tou Nēsiou [The Crafts in Ioannina and the Monasteries of the Island], in Monastēria Nēsou Iōanninōn, in Garidēs, Miltos; Paliouras, Athanasios (eds). Praktika Symposiou: 700 chronia 1292-1992 (29-31 Maiou 1992) [Monasteries of Ioannina Island. Proceedings of the Conference for the 700th Anniversary, 1292-1992 (May 29-31, 1992)]. Ioannina: Panepistēmio Īōanninōn Publ., 1999. Pp. 535-546. (in Greek). 
Petković, Sreten. Zidno slikarstvo na području Pećke Patrijaršije 1557-1614 [Wall Painting on the Area of Patriarchate of Peć 1557-1614]. Novi Sad: Matica srpska Publ., 1965. 361 p. (in Serbian).

Radujko, Milan. Fresco Program around the «King's» Throne, in Mural Painting of Monastery of Dečani. Material and Studies. Ed. by Vojislav J. Djurić. Beograd, 1995. P. 301-307.

Sarros, Dēmētrios. Ėpeirōtikai enthymēseis è chronika sēmeiōmata kai epigraphai [Epirote memorial and chronographic notes and inscriptions], in Ëpeirōtika Chronika. 1937. Vol. 12. Pp. 104-132. (in Greek).

Skeuophylakio Monēs Eleousas sto Nēsi tōn Iōanninōn. Oi phorētes eikones [Sacristy of Eleusa Monastery on Ioannina Island. The Icons]. Ioannina: Ypourgeio politismou kai athlētismou, Ephoreia archaiotētōn Iōanninōn Publ., 2017. 141 p. (in Greek).

Tourta, Anastasia. Monē Prodromou Nēsou Iōanninōn. Oi Apsarades kai ta idrymata tous [The Apsarades and their foundations], in Garidēs, Miltos; Paliouras, Athanasios (eds). Monastēria Nēsou Iōanninōn, Praktika Symposiou: 700 chronia 1292-1992 (29-31 Maiou 1992). Ioannina: Panepistēmio Iōanninōn Publ., 1999. Pp. 343-355. (in Greek).

Trifonova, Alexandra. Oi toichographies tou Agiou Geōrgiou tou Bounou stēn Kastoria. Symbolè stē meletē tès zōgraphikēs tou deuterou misou tou $140 u$ aiōna stèn euryterē periochè tès Makedonias [The Frescoes of St. George tou Vounou in Kastoria. For the Study of Painting of the Second Half of the 14th Century in a Region of Macedonia], PhD Diss. Thessaloniki, 2010. 382 p. (in Greek)

Tsaparlès, Eustratios. Xyloglypta templa Ėpeirou 17ou - a'èmiseos 18ou ai.: Prostypa xyloglypta [Wooden templa of Epirus from the $17^{\text {th }}$ - first half of the $18^{\text {th }}$ centuries: relief wood carving]. Athens: Panepistemio Athēnōn Publ., 1980. 182 p. (in Greek).

Tsigaridas, Euthymios. Kastoria, kentro zōgraphikēs tēn epochē tōn Palaiologōn (1360-1450) [Kastoria, the painting center of Palaiologan period (1360-1450)]. Thessaloniki: Etaireia Makedonikōn Spoudōn Publ., 2016. 631 p. (in Greek).

Vokotopoulos, Panagiōtēs. O Xenos Digenēs stēn Ēpeiro [Xenos Digenēs in Epirus], in Deltion tēs Christianikēs Archaiologikēs Etaireias. 2014. Vol. 35. Pp. 143-182. (in Greek).

Vranousēs, Leandros; Sphyroeras, Vasileios. Dēmographikes exelixeis. Oi Ēpeirōtes tēs diasporas [Demographic developments. Epirotes of the diaspora], in Sakellariou, M. (ed.). Epeiros. 4000 chronia ellēnikēs istorias kai politismou [Epirus. 4000 years of Greek history and culture]. Athens: Ekdotikē Athēnōn Publ., 1997. Pp. 257-264. (in Greek). 